\title{
Victims of Terrorism Between Compensation and Loss of Rights: A Comparative Study Between Iraqi Law and French Law
}

\author{
Ibtihal Zaid Ali \\ University of Baghdad, Baghdad, Iraq
}

\begin{abstract}
The problem of the damage caused by terrorist acts has raised many difficulties in many countries, including Iraq, which requires the existence of a law that sets out sufficient rules for compensating the victims of terrorist acts, in order to compensate them for the harm they have not suffered. It may be difficult or impossible for them to identify causing damage, and therefore unable to obtain compensation by applying the traditional rules of liability that require proof of fault and identify the culprit. The security funds come as an appropriate alternative that pays compensation in such cases for victims to reparation for the damage they suffered. Therefore, this problem remains one of the most problems that Iraq suffers from it, which need to study comprehensively to determine the rules of procedures and necessary instructions to be taken to solve this problem. For that, this study comes to discuss this important and vital subject in order to reach a possible outcome to overcome this problem.
\end{abstract}

Keywords: terrorism, Iraqi, law, compensation, rules

The world has known a wave of violence that has caused panic and terrorized the safe people. The world has found itself facing challenges not only political but also more social, necessitating the search for means of prevention and dealing with its consequences. Terrorism has become a social phenomenon that requires the establishment of the legal rules that govern it. It is a physical or financial damage to civilian personnel, and thus, entitles victims of terrorist acts according to the general rules to file a lawsuit to compensate for the harmful act. However, civil responsibility in its traditional rules does not guarantee compensation for the damage caused by terrorism.

It can therefore be argued that the civil liability case, which represents the individual protection of victims of terrorism, is fraught with danger, because it is difficult to identify the responsible or guarantor, the difficulties of litigation, the proceedings, and the position of the weak victim in the face of terrorism. The most important of solutions to the problems resulting from terrorism is the determination of the obligor to compensate for those damages. The most important of these proposals is the state's obligation to compensate the victims of terrorism because of the lack of rules of civil liability and the creation of new rules of liability. Despite the lack of knowledge of the official lies the importance of compensating the victims, it is often the culprit remains unknown or because of the gravity of the damage to the offender is unable to pay compensation, so it was incumbent on the state to compensate the victims of terrorism.

Corresponding author: Ibtihal Zaid Ali, M.A., College of Political Science, University of Baghdad, Baghdad, Iraq; research fields: private law and civil law. 
The aim of the research is to discover the Iraqi legislator's treatment of the damage caused by terrorism, how to compensate for it, the extent of this compensation compared to the French legislator, and to make recommendations to the Iraqi legislator in case of failure to solve the problem of compensation for victims of terrorism.

The research will be based on a comparative descriptive analytical approach by presenting the problem and solutions, and analyzing them in order to draw conclusions from them. Therefore, we will divide the research into two sections: (1) compensation for those affected by terrorism under the September 9, 1986 French law; and (2) compensation for victims of terrorism under the First Amendment Law as a result of military operations and military errors and terrorist operations No. 57 for the year 2015 .

\section{Compensation of Those Affected by Terrorism Under the Law of 9 September 1986 French}

This law refers to the circumstances surrounding France in the period from September 4 to September 17 in 1986. During this period, six terrorist incidents resulted in many deaths and injuries, as well as serious damage, and the general rules have reflected the need to redress these damages. The former laws, in particular the law of January 3, 1977, and the inadequacy of these laws compensate for the damages. Many parties resorted to solidarity to redress the damage by establishing a special fund for victims of terrorism (Mustafa, 1986). The French legislator formed a fund known as the "Legal Under Any Other Law". The basis of the principle of compensation from the fund is not based on the provisions of civil liability, but rather on considerations of social solidarity. This has been confirmed by the French Court of Cassation in many of its provisions (El-Faki, 2003).

The French legislature has resorted not only to the tightening of the penalty. In accordance with the provisions of Article L.126-1 of the French Insurance Act, the beneficiary of this system is all the victims of terrorist acts in France, regardless of whether the victim is a French or a foreigner, and also applies to the injured persons in the terrorist incidents of the French fall outside France (Khudair, 2005). Under this law, victims are compensated for the physical damage they suffered from the guarantee fund. In the Act of September 9, 1986, the French legislator denied the criticism of the Act of January 3, 1977 and compensated the damage including a ceiling of 150,000 francs to 400,000 francs in 1986. Until the amendment was made in 1990, the legislator had tried to put an amount to force the damage not to exceed. But the acts of terrorism that occurred in 1986 gave rise to this law impact on the law to take the principle of full compensation for physical damage as a result of business. In the sense, he did not distinguish between the damages. The legislator has come out on the precautionary principle, which makes the compensation that the victim deserves to be of a reserve nature as well as being a mere aid, rather than a real compensation. He has become a real, complete, and speedy compensation, and adopts the principle of immediate compensation (Ibrahim, 2000).

The legislator has allowed supplementary compensation for the aggravation of bodily harm that has already been compensated. The victim may return to the fund after receiving the initial compensation. If the fund does not meet this, the rules of civil liability of the victim are not in accordance with the conditions and procedures stipulated in Article 9 (3) of the Law of September 9, 1986. The legislator undoubtedly knows the extent of the damage caused by acts of terrorism, which extends for long periods. Therefore, he should expect the physical and psychological damage caused by these crimes to be aggravated after the claim and exceeds the amounts of the previous compensation obtained. This undoubtedly guarantees the rights of the physical victim and maintains dignity, and agrees that this law has been enacted for it. In all cases, it may not be sentenced to supplementary compensation only if the victim established evidence that physical injury has worsened in the period between the 
accident and the application. It is worth mentioning that the French law has arranged the death of the victim of terrorism crimes in a more comprehensive and comprehensive manner. It states that the victim has the right to obtain benefits related to public service, social and health security, benefits to veterans and invalids. The French courts differed between the positions of the civil service, and agreed to grant relatives the right to compensation for moral damage and some stipulated that the damage was serious.

Therefore, the condition that the damage was a direct and personal result of the crime, and those who suffered indirect damage cannot file a claim for compensation. In the case of the community departments of the Court of Cassation adopted the view of the criminal chamber, it ruled that relatives may not be required to compensate for damage caused by a relative injury to them, whether physical damage or purely physical damage. But if the damage to relatives is the death of this relative, relatives may compensation for moral damage apostate as compensation of children. The author thinks that the French legislator has done well with the privileges and rights that he has given to the victims of terrorism. He has taken into account the principle of full compensation for all physical damages such as injury, death, subsequent loss, and gain (El-Feki, 2003). The French legislator has placed the injured party in the right to claim compensation for future damage, as well as compensation in the event of an aggravation of the damage as it stipulated the obligation of the fund to offer compensation to the victim within one month. This offer is also provided if the damage is proved to be aggravated. The psychological damage caused by the crime of terrorism is the legislative amendment enacted by the French legislator by the law of July 6, 1990 and also became violent crimes compensation for moral damage. As for the purely physical damage, the French legislators has completely excluded it through the security fund and enter into insurance contracts and the obligation of insurance companies to cover these losses as well as the order of invalidity. The question of the direct financial damage caused by the crime of terrorism and the extent of the obligation of the security fund to compensate for it are not mentioned in French law, and therefore, it falls within the scope of financial damages for purely covered by insurance.

The victim receives compensation from the fund through a request submitted to the fund's administration, including his statements, a statement of the terrorist incident, annexing the documents proving the damage, and a statement of the previous compensation for the same damage to be compensated (Pradel, 1983). The French legislator took into account that the victim of the terrorist act is unable to file a lawsuit against the perpetrator of the terrorist act as well as the possibility of not being able to go to the fund to request the payment of compensation. So, he did not specify the duration of the application and the victim has the right to demand quick aid. After the amendments made by the law of July 6, 1990, the application for aid shall be determined within one month from the date of submission of the application. When the validity of all the information and data of the security fund is verified by the injured person or through the use of the competent authorities, the decision shall be made on the amount of compensation (Khudair, 2005).

This amount shall be paid within one month after the expiry of the notification period if the injured party accepts the offer and reconciles with the fund after deducting the amounts obtained as an aid. In the case of the applicant for compensation being a minor or subject to guardianship according to the Article L.422-2 of the Insurance Law, the guardianship judge must be informed of this offer and the student of guardianship may revoke the peace within 15 days. This condition of public order cannot be violated even by agreement between the victim and the fund in accordance with Article L.211-16 of the Insurance Act. This does not affect the injured person's right to claim supplementary compensation in the event of an increase in damages, such as the fact that the act has caused injuries to be remedied and others that require a period of time in accordance with the circumstances of 
each case. Based on the damage and submitted by the injured documents, the victim rejected the offer of the Criminal Court may suspend the civil. If there is a criminal case involving the same case, the dispute between the fund and the injured party shall not cease until the conclusion of the criminal proceedings. The French legislator decided in Article L.422-3 that the civil judge has to adjudicate the dispute before him without waiting for the verdict of the criminal judge. We see that the civil judge is not related to the existence or absence of the damage but relates to the amount of material. The civil suit is not required by the civil judge, but the amount of compensation for the injured person shall be determined in accordance with Article 2270 of the French Civil Code. The case shall be filed within 10 years from the date of the damage being investigated or aggravated. Upon the issuance of the judgment of the court and determination of the amount of compensation due to the victim, the fund is obliged to pay the said amount or is subject to the calculation of the delay benefits specified by the legislator by $50 \%$ after the expiry of two months multiplied to $100 \%$ after the expiry of four months from the date of the judgment if he is present or from the date of the announcement of the fund. We can say that it is sufficient that the fund works to protect the victim and the formation of the government, and therefore, the obligation is available and it is enough to alert the specialist quickly to implement this in accordance with the circumstances of the victim ${ }^{1}$.

The guarantee fund shall be replaced in accordance with the provisions of Article 3 (9) of the Law of September 9, 1986, Article 3 of the Law of December 30, 1987 replaces the victim to claim his rights in the face of the official and to intervene before the criminal court, which considers the case, even for the first time before the Court of Appeal to claim the rights of the injured, and may file an original civil suit and take all the ways allowed by law to obtain the rights of the victim (Pradel, 1983, p. 241). The solution of the box is only in the hand. The damage to the injured person, including bodily injury, injury to body members, injury and moral damage, and financial damage to the injured does not compensate the fund, but compensates the insurance companies in case of insurance from terrorist incidents. The insurance companies are replacing the injured in the face of the official if the injured person is not insured, he has recourse to the person responsible for the amount of material damage he is entitled to, and the injured party is entitled to compensation from the official in the elements of material damage and leaves the fund with the claim of the official in bodily harm. The judge may rule in each case alone and the compensation shall include all the damage caused by the official and the injured person who shall have been fully compensated for all physical and material damages suffered.

\section{Compensation for Victims of Terrorism Under the First Amendment Law of the Law for the Compensation of Victims of War Crimes, Military Mistakes and Terrorist Acts No. 57 of 2015}

The position of the jurisprudence and the judiciary to compensate the victims of terrorist acts is based on the dedication of the state officials to compensate the victims of terrorist acts. In this manner, the Iraqi constitution was enacted in $2005^{2}$. Accordingly, the law of compensating those affected by military operations, military errors and terrorist acts No. 20 of 2009, any person who has suffered harm as a result of military and terrorist operations and military errors shall be compensated. He shall also specify the damage, its severity, the basis for its compensation, and how to claim it ${ }^{3}$. The first amendment to the Law of Compensation for Victims of War in

\footnotetext{
1 Dr. Ahmed Abdul Latif, the source, p. 527.

2 This is stated in Article 132 (b) of the Iraqi Constitution of 2005.

3 Article (1).
} 
accordance with the provisions of Law No. 20 for the year 2009 and in terms of the rights and privileges covered by the provisions of the Law of the Martyrs Foundation No. 3 for the year 2006, establishing a department in the Martyrs Foundation concerned with those covered by the provisions of this law and to simplify the procedures for the work of the subcommittees. The central committees address the practical application of the law and improve the living conditions of those categories and compensate for what they suffered. Under this law, compensating every Iraqi natural or moral injury caused military and terrorist operations and military errors after the law of origin, not including the legal person and the legal acts committed by the legislator. Terrorist and military acts and attacks were not aimed at a particular person, and moral persons contributed greatly to the roles assigned to them by the law. They were established under the law. It was necessary to provide legal protection for their money, which is an imperfect part of the financial responsibility of the Iraqi economy. The first amendment to the Law for the Compensation of Persons Affected by War Crimes, Military Mistakes and Terrorist Acts No. 57 of 2015 has been replaced by a legislative vacuum, but without retroactive compensation for those who have been injured.

The law provided for the formation of central and sub-committees to compensate the affected persons according to the law ${ }^{4}$. The tasks of these committees differ in whether the committee is a subsidiary or a central committee accordingly ${ }^{5}$. However, the work of the committees is focused on receiving applications and estimating the value of compensation. The Ministry of Finance and the Ministry of Finance can object to the recommendations of the subcommittees and committees formed by the ministries and entities not associated with the Ministry of the Central Committee within 30 days from the day following the date of notification ${ }^{6}$. The possibility of combining the compensation provided in this law of compensation for the damages according to the law of another and in the case of the victim for compensation less than what it deserves, this law gives the difference between what distract him and deserved under this law ${ }^{7}$.

The victim's relatives must submit an application clarifying the exposure of their relatives to a terrorist act or military and military error to a secretarial office managed by an employee who holds an initial university degree. It is assisted by a number of staff assigned by the province or governorate not organized in a region accompanied by the required documents mentioned in the instructions, which is headed by a judge with representatives from multiple ministries and a representative from each governorate. The subcommittee, in turn, recommends a compensation for the injured party and issues a decision to monitor the funds for it, which is delivered directly ${ }^{8}$ and civilian martyrs ${ }^{9}$.

After review of the compensation mechanism granted under the First Amendment Law to the Compensation of Victims of War, Military Mistakes and Terrorist Acts No. 57 of 2015, it is complicated and involves routine procedures that require the victim to wait for a period of time until the committees complete their procedures due to the large number of requests resulting from frequent occurrence terrorist acts in Iraq. This law is also taken into account in compensating the victims of terrorist operations. It can be said that the amounts awarded as compensation to victims of terrorist acts are small amounts that are not commensurate with the amount of damage. Compensation for the amounts specified in advance under the scales did not take into

\footnotetext{
4 This is stated in Article 3.

5 This is stated in Article 5 first.

6 This is stated in Article 7.

7 This is stated in Article 8.

8 This is stated in Article 6 (IV).

9 This is stated in Article 9 first.
} 
account in assessing the personal differences of each person and the extent of the reflection of the damage to him and his daily life and future; it is an assistance provided by the state does not amount to the level of compensation for the damage caused by terrorist acts.

In order to alleviate the burden on the public budget, we propose a similar security fund for the French security fund. The provisions of the law stipulate the establishment of a special fund for the victims of terrorism. Any person who may have caused the terrorist incident committed inside Iraq (whether Iraqi or foreign nationals) shall be compensated for. The legislator must put in place a system of rapid compensation. The injured party is entitled to call for a quick aid to redress the damages that occurred to him. The request for aid shall be stopped within a short period of 15 days. The fund shall verify the information and data of the injured persons through the assistance of in the competent authorities and the victim shall be granted such aid upon consideration of full compensation thereafter. The victim shall be informed of the termination of the letter with the knowledge of the arrival. As for the proposed composition of the security fund, we shall consider that it shall consist of a president and members appointed by the president by a decision of the prime minister. The ministries of interior, finance, health, and justice are appointed by a decision of the competent ministers, in addition to specialists in the fields of insurance and members of civil organizations in this regard. The council is appointed for a renewable year and is subject to the supervision of the concerned bodies in financial aspects. From the date of issuance, Mnha.ottkon exchange funds from the state fund contributions have a direct ratification in addition to the fee recognizes companies and institutions with large acceptance of donations, and the operation of the fund's money in the business in the absence of terrorist acts.

\section{Conclusions}

The phenomenon of terrorism is universal in many states and the traditional foundations of attribution of the principle of remedying the damage caused by terrorism have failed because traditional responsibility, whether on the basis of error or risk, requires damage to positive or negative action. The rules of this responsibility can be implemented only if the damage is relevant to the public facility since the general rules and international conventions have reflected the need to redress the damage caused by terrorism. This is evident in France and some countries in compensating the injured and it was necessary to seek solutions based mostly on legislative texts that define the rules for ensuring the victims of terrorism. The jurisprudence has succeeded in finding a standard to support the victim and tried to employ the principle of social solidarity and some principle of human rights in security, but he could not construct an integrated theory that serves as a philosophical basis to support the principle of repairing the damage caused by terrorist acts. The judge is still unable to grant full compensation or absence of legislative text.

We propose the establishment of a fund to compensate the victims. In terms of financing the fund, it is possible to diversify its sources of funding from the state treasury and voluntary contributions. The important thing now is the decision of the principle and the establishment of mechanisms or regulations that specify the conditions for obtaining assistance and how to assess compensation.

\section{References}

Abdullah, F. A. R. (2005). Studies in tort liability: Towards objective responsibility. Alexandria: Knowledge Establishment. Al-Zaqard, A. A.-S. (1997). Compensation for damage resulting from terrorism crimes. Journal of Law-Kuwait, Q21, 3. El-Faki, A. A.-L. (2003). The state and the rights of victims of crime. Cairo: Darf Al-Jafarl Al-Nashr Al-Shuhoora. French Criminal Procedure Act. 
Ibrahim, T. A. M. (2000). Problems of compensation for physical damages in civil law in the light of jurisprudence and jurisdiction. Dar Al-Fikr and Mansoura Law.

Khudair, T. F. (2005). Compensation for victims of crime in light of the traditional principles of state responsibility. Journal of the Police Research Center, C2, 27.

Law of compensation for those affected by military operations, military errors and acts of terrorism No. 20 for the year 2009 .

Law of the first amendment to the law of compensation for those affected by military operations and military errors and terrorist operations No. 57 for the year 2015.

Mansour, M. N. E.-D. (2001). Guaranteeing compensation of the injured between the rules of individual responsibility and considerations of social solidarity. Arab Cairo: Dar al-Nahda.

Mustafa, A.-S. A.-B. (1986). Insurance general principles and insurance contract. Mansoura: Al-Jalala Library.

Permanent Iraqi Constitution of 2005.

Pradel, J. (1983). Un nouveau stade dans la protection des victimes d'infractions (A new stage in the protection of victims of crime). Dalloz-Sirey, Chronique XLIII.

Social and Health Insurance Law of 23 January, 1990. 